\title{
LOCALLY PROCESSED ROASTED-MAIZE-BASED WEANING FOODS FORTIFIED WITH LEGUMES: FACTORS AFFECTING THEIR AVAILABILITY AND COMPETITIVENESS IN ACCRA, GHANA
}

Nagai $\mathrm{T}^{*}$, Staatz $\mathrm{JM}^{2}$, Bernsten $\mathrm{RH}^{3}$, Sakyi-Dawson $\mathrm{EO}^{4}$ and GA Annor ${ }^{5}$

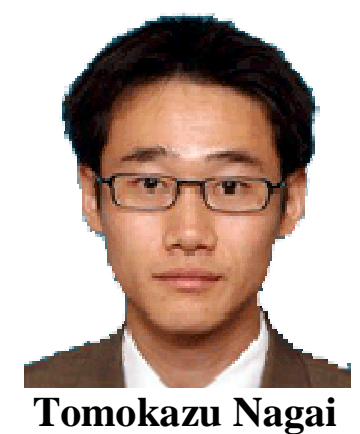

*Corresponding author email: nagaitom@msu.edu and t.nagai@ntc-i.co.jp

${ }^{1}$ NTC International Co., Ltd., 5 Yotsuya 3-Chome, Shinjuku-ku, 160-0004, Tokyo, Japan

2 Department of Agricultural, Food, and Resource Economics, Michigan State University, 205 Agriculture Hall, East Lansing, MI48824-1039, USA

3 Department of Agricultural, Food, and Resource Economics, Michigan State University, 211E Agriculture Hall, East Lansing, MI48824-1039, USA

4 Department of Nutrition and Food Science, University of Ghana, P.O. Box LG 134, Legon-Accra, Ghana

5 Department of Nutrition and Food Science, University of Ghana, P.O. Box LG 134, Legon-Accra, Ghana 


\section{ABSTRACT}

Tom Brown (roasted-maize porridge) is one of the traditional weaning foods in Ghana. As an effort by the Ministry of Health to enhance the nutrient content of this lownutrient-density weaning food, a product called weanimix, which is Tom Brown fortified with legumes (cowpeas or soybeans and groundnuts), was introduced more than two decades ago. Cowpeas are an indigenous African legume, popularly used by Ghanaians for various traditional dishes. While soybeans are not traditionally used, they can easily be incorporated into local diets. Commercial weanimix-type products in ready-to-cook flour form are currently available mainly at supermarkets, which target higher-income consumers. This paper examined: (1) the competitiveness between cowpeas and soybeans as an ingredient in weanimix; and (2) constraints to making weanimix more widely available to lower-income families. Local food processors, weaning mothers, commercial custom millers, and retailers were interviewed for both qualitative and quantitative data. Secondary price data were collected from different sources including the Ministry of Food and Agriculture. Descriptive analysis was carried out to address non-price factors of the issues, and enterprise budgeting and sensitivity analyses were conducted to address price factors. The study found that the higher price of cowpeas, compared to soybeans, is a minor factor in local processors' choice between cowpeas and soybeans. Rather, the current overwhelmingly popular use of soybeans in the weanimix-type products among the respondents was attributed to non-price factors such as the perception that soybeans are more nutritious. A main reason for the lack of availability of weanimix for mothers from lower-income families appeared to be low awareness of the product among consumers. The results of sensitivity analysis showed that typical differences in prices currently observed between weanimix-type products and Tom Brown seems to be larger than the difference in the cost of production between these products. It was also shown that the level of processing and retail margins greatly affect the retail prices of weanimix. Weanimix could be made more available to lower-income consumers if local companies expanded their outlet for the product from supermarkets to small shops or if grain and flour-type product vendors in the local markets (who currently prepare and sell Tom Brown) produced and sold weanimix. However, actions would need to be taken to help assure consumers of the quality of the product sold through market vendors.

Key words: weaning food, cowpeas, soybeans, Ghana 


\section{INTRODUCTION}

In West Africa, cereals are the main ingredients in most of the traditional weaning foods. However, since the nutrient density of these weaning foods is low, it is almost impossible for small children to meet their needs for calories and protein from the amount that they can ingest. Sources of good quality protein such as meat are expensive for low-income families [1,2]. Many studies have examined how to improve the nutritional quality of traditional weaning foods using affordable staples such as legumes [1, 3-11]. In Ghana, one of the traditional weaning foods is a roastedmaize-based porridge popularly called Tom Brown. Like many other cereal-based weaning foods used in the region, Tom Brown is relatively low in protein. To enhance its nutrient content, in 1987 the Ministry of Health and the United Nations Children's Fund introduced a product called weanimix, which is a fortified Tom Brown composed of $75 \%-80 \%$ maize, $10 \%-15 \%$ cowpeas or soybeans, and $10 \%$ groundnuts [9]. Lartey et al. [9] showed that in their study in the Brong Ahafo region, children who were given weanimix demonstrated better growth compared to those who were not given. Colecraft et al. [12] also reported that in nutrition rehabilitation centers in Accra, weanimix was among the food items used in their supplementary feeding program for improving the health situation of malnourished children. Thus, weanimix does appear to have significant nutritional advantages for young children over Tom Brown.

Cowpea (Vigna unguiculata L. Walp.) is a drought-tolerant indigenous African legume, which is used in various traditional dishes [13-15]. On the other hand, while soybean (Glycine max L. Merrill) is not an indigenous legume in Ghana, its use in weaning foods has been promoted by the Ministry of Health [16,17]. Compared to soybeans, cowpeas are lower in protein (23\% vs. 34\%) and fat content (1\% vs. $18 \%)$, but higher in carbohydrates (61\% vs. 34\%) [18]. Despite cowpeas' lower protein and fat content, the standard weanimix recipe uses the same percentage of cowpeas or soybeans (10\%-15\% in terms of the weight in inputs) as a fortifier. Possibly the Ministry of Health developed a single recipe so relatively uneducated mothers could easily prepare weanimix, using either cowpeas or soybeans. While both cowpeaweanimix (Tom Brown fortified with cowpeas and groundnuts [Arachis hypogaea L.]) and soybean-weanimix (Tom Brown fortified with soybeans and groundnuts) meet the minimum nutrient composition for a weaning food, if a recipe was set to just meet the minimum nutrient composition, more cowpeas (compared to soybeans) would need to be used.

Although cowpeas are popularly consumed at home, various constraints to use them as an ingredient in processed products have been identified $[19,20]$. Such constraints include fluctuations in price and quality, lack of stable availability, and possibly poor functionality of processed products. Moreover, cowpeas are generally more expensive than soybeans. Nonetheless, researchers working on cowpea development are interested in promoting their use in processed products. They believe that the popularity of cowpeas in West Africans' daily diet indicates a high potential for their use in processed products and that increased consumption and utilization of cowpeas, 
which are important as a both food and cash crop in the region, would improve the food security of a large share of the population-from farmers to consumers.

Since weanimix's introduction two decades ago, home preparation of this weaning food has not been widely adopted possibly due to its higher cost and longer time required to prepare it, compared to Tom Brown. Plahar et al. pointed out the inconvenience and possible cost ineffectiveness of processing such a weaning food at the household level, and suggested small-scale enterprise development as a possible solution [11]. In Accra, the major sellers of commercial Tom Brown (in a ready-tocook dry flour form) are grain and flour-type product vendors in the local market (referred to in this paper as "G/F vendors"), who use a commercial custom miller to grind the grain and prepare Tom Brown themselves. However, these vendors rarely prepare and sell weanimix. Currently, a limited quantity of commercial weanimix-type products is mostly produced by small- to medium-scale local food processing companies (referred to in this paper as "local companies") that usually produce different types of flour products. However, these weanimix-type products are mainly sold at supermarkets, which target higher-income consumers. Therefore, these products are not readily purchased by mothers from lower-income families whose children would most benefit from them. (In this paper, the term "weanimix-type product" is used to include products similar to weanimix but made with ingredients or composition of ingredients different from the standard weanimix recipe.)

This paper presents the results of a study carried out in Accra, Ghana, in 2007 in order to: (1) examine the competitiveness between cowpeas and soybeans as an ingredient in weanimix; and (2) analyze constraints to make weanimix widely available to lowerincome consumers. Both non-price and price factors are considered.

\section{METHODS}

Field work was conducted in the Greater Accra Region during February and March 2007. Using structured questionnaires, interviews were conducted with ten local companies, 30 weaning mothers, 15 custom millers, and 18 retailers (seven G/F vendors, seven small shops, and four supermarkets). Both qualitative and quantitative data were collected. To ensure that enough information could be collected from each respondent, a purposive (non-probability) sampling method [21], rather than random sampling method, was used; that is, screening was done before beginning interviews and potential respondents who did not meet the criteria were excluded (for example, only local companies producing either Tom Brown or weanimix-type product were interviewed). To interview weaning mothers, a hospital and three clinics were visited on their "weighing day," when mothers could have their small children weighed.

For different grain crops, a representative price in February 2007 and the lowest and highest prices during the year were estimated using data collected from: (1) the Ghanaian Ministry of Food and Agriculture; (2) Tradenet (http://www.tradenet.biz), a website providing up-to-date price data of different commodities mainly in West African countries; (3) personal observations in the local market; and (4) personal

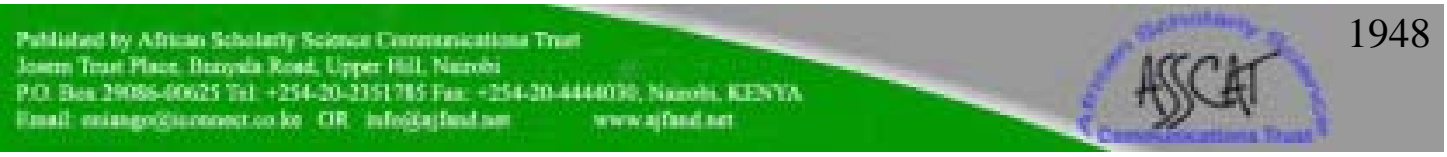


communication with a wholesaler and street vendors of koose (cowpea fritter), who buy cowpeas on a regular basis for their business.

Descriptive analysis was carried out using the qualitative data to examine non-price factors affecting: (1) the competitiveness between cowpeas and soybeans as an ingredient in weanimix; and (2) the potential for commercial weanimix to become more widely available.

Enterprise budgeting analysis [22] was conducted using the quantitative data collected from the survey respondents and the derived representative prices of grain crops to analyze the price-competitiveness between cowpeas and soybeans as an ingredient in weanimix, as well as the price-competitiveness between Tom Brown and weanimix. Unfortunately, five out of the ten local company respondents could not provide enough information to construct budgets. Therefore, based on the data collected from the remaining respondents, five enterprise budgets for producing $1 \mathrm{~kg}$ of Tom Brown, cowpea-weanimix, and soybean-weanimix were constructed. In the weanimix budgets, the share of each ingredient was set the same across the respondents as follows: $75 \%$ maize, $15 \%$ cowpeas (soybeans), and 10\% groundnuts. From the five budgets, two representative budgets were constructed for each of the three products, as follows: first, after selecting the two budgets having the lowest net returns, a low-profit representative budget was constructed by using the mean value of the net returns and each cost component in these budgets. Second, after selecting the two budgets having the highest net returns, a high-profit representative budget was constructed by using the mean value of the net returns and each cost component in these budgets. Finally, to estimate the retail prices of the products, a retail margin was added to the processor price in the two representative budgets. For the value of the retail margin, the mean retail mark-up among the small shop respondents was used. As opposed to supermarkets, which are the current major outlet for local companies' weaning foods, small shops rarely sell these products. However, if commercial weanimix is to become widely available, small shops are potentially important outlets because nearly everybody, including lower-income consumers, shops at these retail outlets.

Although most G/F vendors do not currently prepare and sell weanimix, enterprise budgets for producing $1 \mathrm{~kg}$ of cowpea-weanimix and soybean-weanimix were also constructed, based on the data collected from the G/F vendor respondents on their cost of producing Tom Brown. The derived prices of their weanimixes were compared with the estimated retail prices of local companies' weanimixes.

Finally, sensitivity analysis was conducted to examine how the results of budgeting analysis would change when key variables in the budgets change. Five examined scenarios are: (1) change in local companies' technical efficiency (i.e., how much waste of raw materials occur during processing); (2) increase in capacity utilization by local companies; (3) variation in the price of raw materials; (4) variation in retail margins; and (5) combinations of different scenarios. Further details of the methods and models used are described in Nagai [23]. 


\section{RESULTS}

\section{Price differences among weaning foods available in Accra}

A wide difference was found among the prices of existing weaning foods in Accra (Table 1). While weanimix-type products manufactured by small- to medium-scale local companies were priced much lower than weaning foods manufactured by largescale multinational companies, the mean price of local companies' weanimix-type products was $\phi 6,900 / \mathrm{kg}$ (US $\$ 0.75$ ) higher than the mean price of local companies' Tom Brown and $\$ 9,600 / \mathrm{kg}$ (US\$1.04) higher than the mean price of G/F vendors' Tom Brown (US $\$ 1$ = approximately $\phi 9,200$ [Ghanaian cedis] during February and March 2007. In July 2007, Ghana denominated its currency, and $\notin 10,000$ became $\mathrm{GH} \notin 1$. However, the currency of the time when the survey was conducted is used throughout this paper).

\section{Weaning mothers}

Among the 30 weaning mothers interviewed, Tom Brown and weanimix were not popular weaning foods. Of the 23 respondents who prepared weaning foods from raw materials, only two mentioned Tom Brown or weanimix as one of their three mostoften-prepared weaning foods, as opposed to koko (porridge made from fermented maize dough) or banku (also made from fermented maize dough, but more solid than koko), which were mentioned by 20 respondents. Of the 26 respondents who purchased commercial weaning foods, only three mentioned Tom Brown or weanimix as one of their three most-often-purchased weaning foods, as opposed to Nestlé Cerelac, which was mentioned by 23 respondents. In fact, the majority of the 30 respondents had never purchased weanimix, and many of them had never seen it or did not know what it was.

Of the 23 respondents who prepared weaning foods from raw materials, 19 used soybeans, while 17 used cowpeas as an ingredient in their weaning foods. However, if the criterion is limited to the ingredients used in the three most-often-prepared weaning foods, 15 used soybeans, while only two used cowpeas.

\section{Local food processing companies}

Characteristics of the ten local companies interviewed are summarized in Table 2. Most respondents were small-scale processors having fewer than 15 workers (including family members). Most of them did not specialize in flour-type products, but also processed other products (for example, honey, spices, and groundnut paste). The majority of them had produced weanimix-type products for fewer than five years. The share of weanimix-type product in their total revenue varied across the respondents. For many of them, the share of each ingredient differed greatly from that of the standard weanimix recipe (maize $75 \%-80 \%$, cowpeas or soybeans $10 \%-15 \%$, and groundnuts $10 \%$ ). The majority of these weanimix-type products were actually sold (labeled) as Tom Brown.

Among the ten respondents, one produced a weanimix-type product containing cowpeas. This respondent had no special reason for using cowpeas rather than 
soybeans. Another one produced a weanimix-type product containing both cowpeas and soybeans. The other eight respondents produced a weaning food containing soybeans. Advantages of using soybeans mentioned by the respondents included their perceptions that: (1) soybeans are more nutritious (mentioned by three respondents); (2) soybeans have nice aroma/better taste (each mentioned by one respondent); (3) storage is easier (one respondent); and (4) their price is lower (one respondent). Another respondent mentioned that he chose soybeans because he heard that consumer awareness of soybeans was increasing. As disadvantages of using cowpeas, one respondent mentioned that cowpeas would cause gas in the stomach, and another one mentioned that it was difficult to obtain a constant supply of some varieties of cowpeas.

Estimated retail prices of Tom Brown, cowpea-weanimix, and soybean-weanimix Table 3 presents the derived representative budgets to produce $1 \mathrm{~kg}$ of Tom Brown, cowpea-weanimix, and soybean-weanimix, as well as their estimated retail prices. G/F vendors, who currently sold Tom Brown at $\phi 14,300 / \mathrm{kg}$, were estimated to be able to sell cowpea-weanimix at $\phi 15,400 / \mathrm{kg}$ and soybean-weanimix at $\phi 15,100 / \mathrm{kg}$. On the other hand, the estimated retail prices of these three types of weaning foods, if produced by local companies and sold at small shops, were higher-ranging from $\phi 18,300 / \mathrm{kg}$ for Tom Brown, $\phi 19,800 / \mathrm{kg}$ for cowpea-weanimix, and $₫ 19,400 / \mathrm{kg}$ for soybean-weanimix, if produced by low-profit processors; and $\notin 17,500 / \mathrm{kg}$ for Tom Brown, $\notin 18,900 / \mathrm{kg}$ for cowpea-weanimix, and $\phi 18,500 / \mathrm{kg}$ for soybean-weanimix, if produced by high-profit processors.

\section{Sensitivity analysis}

The difference between the estimated retail prices of local companies' cowpeaweanimix and soybean-weanimix became smaller when: (1) the technical efficiency of processing increased; (2) the price of cowpeas declined relative to that of soybeans; and (3) the retail margin declined. When the opposite occurred, the difference in the estimated retail prices became larger. Table 4 presents the lowest and highest values of these variables tested in the sensitivity analysis, combined in a way that the difference in estimated retail prices of these products becomes smallest and largest. The difference in the estimated retail prices of the products $(\phi 400 / \mathrm{kg}$ under current conditions) decreased to $\phi 100 / \mathrm{kg}$ under the most favorable scenario for cowpeaweanimix, while it increased to $\phi 700 / \mathrm{kg}$ under the most unfavorable scenario for cowpea-weanimix.

The difference between estimated retail prices of local companies' cowpea-weanimix and Tom Brown became smaller when: (1) the technical efficiency of processing increased; (2) the price of maize grain increased or the prices of cowpea grain and groundnuts declined; and (3) the retail margin declined. When the opposite occurred, the difference in the estimated retail prices became larger. Table 5 was constructed in the same way as Table 4 . The difference in the estimated retail prices of the products $(\phi 1,400-1,500 / \mathrm{kg}$ under current conditions) decreased to $\phi 600 / \mathrm{kg}$ under the most favorable scenario for cowpea-weanimix, while it increased to $₫ 2,400 / \mathrm{kg}$ under the 
most unfavorable scenario for cowpea-weanimix. The change in the prices of raw materials was the main contributor to these differences.

The lowest retail price of local companies' cowpea-weanimix was estimated to be $\phi 12,200 / \mathrm{kg}$, when produced and sold under the most favorable scenario (Table 6). In contrast, the highest retail price was estimated to be $\phi 24,900 / \mathrm{kg}$, when produced and sold under the most unfavorable scenario. The level of retail margin greatly affected the retail price of local companies' weanimix (Figure 1). For flour-type products, the mean retail margin (mark-up) reported by supermarket respondents was $47 \%(\mathrm{n}=3$, standard deviation $=10 \%)$, while the margin for small shops was $29 \%(\mathrm{n}$ $=7$, standard deviation $=11 \%$ ). Also, the level of the processing margin greatly affected the retail price of local companies' weanimix. The price of $\mathrm{G} / \mathrm{F}$ vendors' cowpea-weanimix was estimated to range from $\phi 13,300 / \mathrm{kg}$ to $\notin 16,500 / \mathrm{kg}$, depending on the seasonal change in the prices of raw materials.

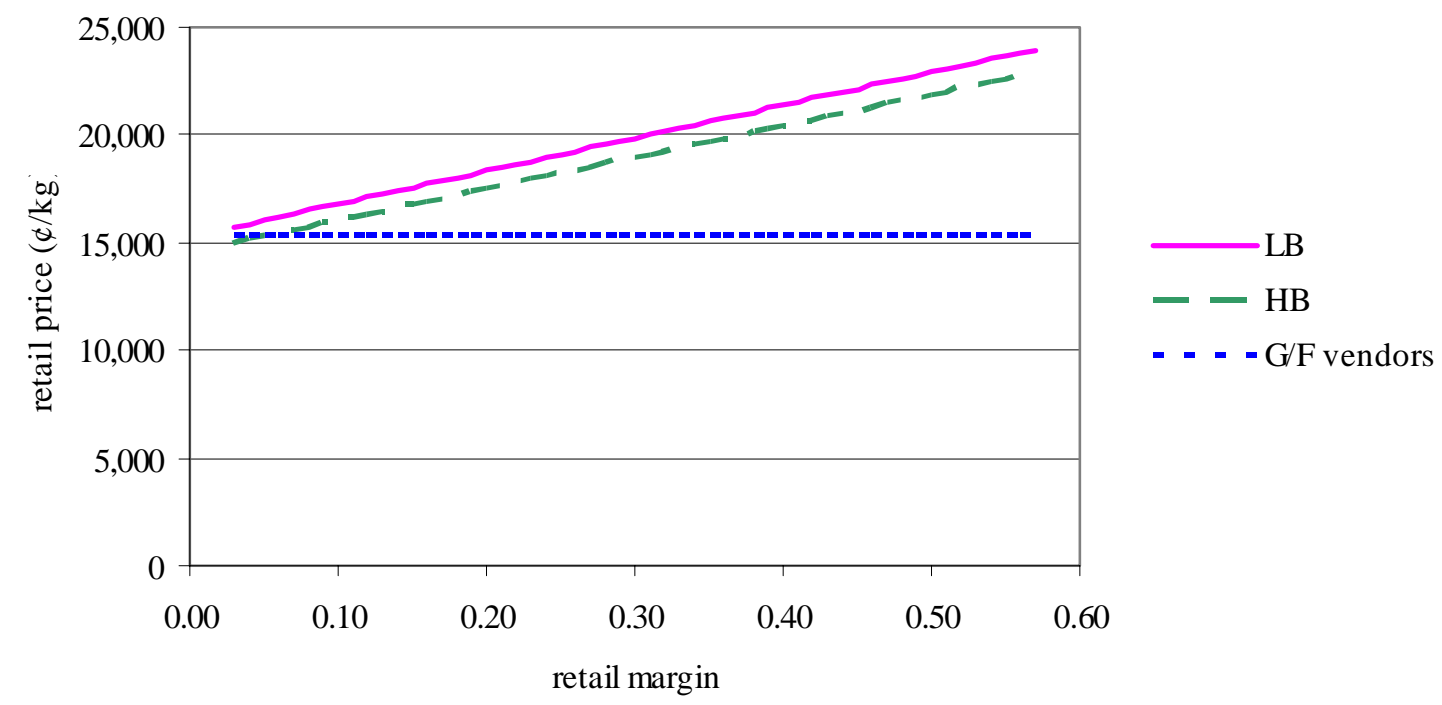

Note: LB: local companies' low-profit representative budget; HB: local companies' highprofit representative budget; $\mathrm{G} / \mathrm{F}$ vendors: grain and flour-type product vendors in the local market

Figure 1: Estimated retail prices of cowpea-weanimix for different levels of retail margins 


\section{DISCUSSION}

\section{Cowpea-weanimix vs. soybean-weanimix}

Although cowpeas were generally more expensive than soybeans, the estimated retail prices of cowpea-weanimix and soybean-weanimix were very similar (maximum difference of $\phi 700 / \mathrm{kg}$ ). This is because the cost share of cowpea or soybean grain (in the total cost of production) was small and the standard recipe for weanimix includes constant proportions of either cowpeas or soybeans, although the nutrient composition of these two pulses varies. Only one local company respondent mentioned the lower price of soybeans as a reason to choose soybeans over cowpeas. Therefore, the current popularity of soybeans over cowpeas among the local company respondents must be attributed to non-price factors.

On the demand side, consumers' preference for cowpeas or soybeans will affect how much more they would be willing to pay for cowpea-weanimix over soybeanweanimix or vice-versa. A study conducted by Mensa-Wilmot et al. in Accra in the early 2000s found that $87 \%$ of 133 weaning mothers who were interviewed used cowpeas in the preparation of weaning foods, while $65 \%$ used soybeans [17]. In contrast, this study found that soybeans were more popular than cowpeas among the 30 weaning mother respondents. This suggests that the popularity of soybeans among weaning mothers may be increasing. Another finding by Mensa-Wilmot et al. suggests that soybean's popularity also varies across regions in Ghana.

As mentioned above, cowpea-weanimix and soybean-weanimix are produced with the same ratio of each ingredient, yet their nutritional values are different due to the difference in nutritional composition of cowpeas and soybeans [18]. In this case, mothers' willingness-to-pay for cowpea-weanimix and soybean-weanimix would be affected by their awareness of, and willingness-to-pay for, the difference in nutritional value of these two products.

\section{Availability of commercial weanimix for lower-income families}

The main reason for the lack of availability of commercial weanimix for lowerincome families appears to be on the demand side, rather than on the supply side. Weanimix was unfamiliar even among weaning mother respondents visiting the postnatal clinics or hospital, although they likely had more opportunities to learn about nutritious weaning foods than other weaning mothers in general. Although some of the local company respondents mentioned that consumer awareness of weanimix had been increasing, the majority of the local company respondents still called the legume-fortified flours "Tom Brown" (instead of "weanimix"), which suggests that the term "weanimix" was not yet widely known. Since it is unlikely that small- to medium-scale local companies could afford to advertise on a large scale, the government (as part of its public-health efforts) and/or professional organizations representing local companies could initiate campaigns as a strategy to further increase 
consumer awareness of legume-fortified maize weaning foods (weanimix), perhaps in collaboration with NGOs that have a child-survival mandate. ${ }^{1}$

The sensitivity analysis showed that the level of retail margin would greatly affect the retail price of weanimix. Therefore, it is recommended that local companies expand their outlets and include small shops (lower retail margin outlets than supermarkets) to make their products more available to weaning mothers from lower-income families.

Also, collaboration between the government-run health clinics/hospitals and local companies could help to make weanimix more available to lower-income mothers. Although a health clinic, which was visited for conducting the weaning mothers' interviews, sold weanimix in small portions, its unit price was higher than the average unit price of local companies' weanimix-type products sold in supermarkets. Therefore, health clinics/hospitals may be able to sell weanimix to mothers at a lower price, by purchasing weanimix in bulk from local companies, repackaging it, and setting its price not to make profit.

\section{Weanimix vs. Tom Brown}

While the mean price of weanimix-type products observed at supermarkets during the fieldwork was $\phi 6,900 / \mathrm{kg}$ higher than the mean price of Tom Brown (Table 1), the results of sensitivity analysis indicated that the difference between the retail prices of weanimix (prepared using the standard recipe) and Tom Brown would be at maximum $\phi 2,400 / \mathrm{kg}$ - if prices were based on production costs. This discrepancy might be because many of the local company respondents used a higher share of fortifier ingredients (cowpeas/soybeans and groundnuts) in their products than the standard recipe. Such a practice would increase the cost of production, compared to the cost of producing standard weanimix, which would lead processors to set a relatively higher price for their weanimix-type products than Tom Brown. Also, local companies might set the price of Tom Brown and weanimix-type products in a way that the price difference between these products is larger than the difference in the cost of production. This could happen if they assume that because the customers for weanimix are higher income, they are willing to pay more for a more nutritionally rich food for their children. Another hypothesis is that local companies are not willing to drop their price of weanimix because they fear that if they price it too cheaply, consumers will interpret this as a signal that the nutritional quality of their product is low. However, as the results of the sensitivity analysis indicate, the relative price between local companies' weanimix and Tom Brown could potentially be smaller than their typical relative prices currently observed in supermarkets-if they produce

\footnotetext{
1 As reported earlier in the results section, it was found that among the weaning mother respondents, koko or banku, both of which are made from fermented maize dough, were much more popular weaning foods than Tom Brown or weanimix. If this is a general trend among Ghanaian weaning mothers, the research on and the promotion of cowpea/soybean-fortified fermented maize dough [3, 24, $25]$ would need further attention.
} 
weanimix using the standard recipe and if they set the prices of these products based on their production costs.

\section{Local companies' weanimix vs. G/F vendors' weanimix}

Under the conditions observed during the fieldwork, $\mathrm{G} / \mathrm{F}$ vendors could sell weanimix at $\phi 3,400 / \mathrm{kg}$ to $\phi 4,400 / \mathrm{kg}$ less than the retail price of local companies' weanimix (Table 3). However, the sensitivity analysis showed that depending on the conditions, local companies' weanimix could be less expensive than $\mathrm{G} / \mathrm{F}$ vendors' weanimix. The only major difference, other than prices, between these products would be that the local companies' weanimix is sold in a sealed polyethylene bag, with a label displaying the Ghana Standards Board certified logo, while the G/F vendors' weanimix would be sold without this kind of air-tight-and-GSB-logo-labeled packaging. Therefore, whether local companies' weanimix would be pricecompetitive with G/F vendors' weanimix would depend on the consumers' willingness-to-pay for a better package and quality certification.

While almost no $\mathrm{G} / \mathrm{F}$ vendors were observed selling weanimix, interviews with $\mathrm{G} / \mathrm{F}$ vendors and custom millers implied that the only difference in costs between $\mathrm{G} / \mathrm{F}$ vendors' preparation of Tom Brown and weanimix would be the costs of raw materials. Since $\mathrm{G} / \mathrm{F}$ vendors prepare their products in large quantities, compared to households, separate roasting of maize, cowpeas/soybeans, and groundnuts to prepare weanimix would require little extra work, compared to the preparation of Tom Brown. Therefore, further research is needed to understand why $\mathrm{G} / \mathrm{F}$ vendors generally do not produce weanimix, because if such a product becomes available, weaning mothers from lowerincome families currently using only Tom Brown might be able to afford the weanimix. A hypothesis is that what discourages $\mathrm{G} / \mathrm{F}$ vendors from selling weanimix is that the majority of weaning mothers who purchase Tom Brown in the local market do not know about weanimix. Therefore, they would not pay a higher price for weanimix, compared to Tom Brown. If this is the case, increase in consumers' awareness of weanimix would be a key to change the situation. Another hypothesis is that without a sealed package, consumers would not trust the quality of the weanimix sold in the open market. They could have concerns about: (1) the composition of the product-is it really weanimix or just Tom Brown (adulteration concern); and (2) its cleanliness (concern about dust/dirt that could get into open sacks in the market). Since mothers' concerns about product quality are likely higher for weaning foods than for other foods, developing a way to certify quality (which probably means sealed packaging, among other things) would be necessary to make the weanimix sold in the market attractive to buyers.

Finally, this study did not collect any information regarding how much weaning mothers from lower-income families could afford to pay for weanimix or weaning foods in general. Thus, it is not clear whether mothers with malnourished children can even afford to purchase Tom Brown sold in the local market, which is among the cheapest weaning foods. These mothers' willingness-to-pay for weaning foods should be examined through a survey, if locally processed commercial weaning foods are to target these mothers. 
Also, it would be necessary to explore why those few weaning mothers who happened to be exposed to weanimix - whether at supermarkets or at health clinics-generally did not become frequent customers of the product and did not play a role to spread out the information on the product among other weaning mothers. This is important because if there are different factors preventing the adoption of weanimix among weaning mothers, merely increasing its awareness will not lead to increase in its use among them. For instance, Colecraft et al. [12] found that the use of weaning foods promoted by the nutrition rehabilitation centers, including weanimix, was limited in the studied mothers' home because of different reasons such as child preferences for tastes and mothers' practice of feeding their children with ready-to-eat foods.

\section{CONCLUSION}

This study found that a higher price of cowpeas, compared to soybeans, is a minor factor in determining the competitiveness between cowpeas and soybeans as an ingredient in weanimix. Most of the local food processing company respondents use soybeans, rather than cowpeas, in their weanimix formulation because of non-price factors, such as the perception that soybeans are more nutritious. On the demand side, the popularity of soybeans appears to vary over time and across regions in Ghana and also depends on consumers' knowledge about the nutritional value of soybeans. These findings suggest the need for a consumer survey among any specific target population of weanimix to assess which type of weanimix would have the greatest potential among that population.

Low awareness of weanimix among consumers was suspected to be a major reason for the current lack of availability of commercial weanimix for lower-income families. Efforts should be made to both increase consumer awareness of weanimix and to lower its price, by working through local food processing companies as well as grain and flour-type product vendors in the local markets.

\section{ACKNOWLEDGEMENTS}

The authors are grateful to the Bean/Cowpea Collaborative Research Support Program (Grant No. GDG-G-00-02-00012-00) and through it, the United States Agency for International Development for funding this study and the Ghanaian Ministry of Food and Agriculture for generously sharing its price data. The authors are also thankful to Dr. Robert Dixon Phillips in the Department of Food Science and Technology at University of Georgia and Dr. James Lowenberg-DeBoer and Dr. Joan Fulton in the Department of Agricultural Economics at Purdue University for their guidance and assistance at the early stage of this study. 


\section{Table 1:Mean prices of different types of weaning foods observed in Accra during February and March 2007}

\begin{tabular}{|c|c|c|c|c|}
\hline Weaning foods & $\begin{array}{l}\text { Low price } \\
\text { during the } \\
\text { year* } \\
(\phi / \mathrm{kg})\end{array}$ & $\begin{array}{l}\text { Price in } \\
\text { Feb/Mar } \\
2007 \\
(\varnothing / \mathrm{kg})\end{array}$ & $\begin{array}{l}\text { High price } \\
\text { during the } \\
\text { year* } \\
(ф / \mathrm{kg})\end{array}$ & Main outlet \\
\hline $\begin{array}{l}\text { Fermented maize dough** (produced } \\
\text { by G/F vendors) }\end{array}$ & $\begin{array}{r}3,200 \\
(400) \\
\mathrm{n}=4 \\
\end{array}$ & $\begin{array}{l}4,500 \\
(600) \\
\mathrm{n}=4\end{array}$ & $\begin{array}{r}6,000 \\
(1,100) \\
\mathrm{n}=3 \\
\end{array}$ & Markets \\
\hline G/F vendors' Tom Brown & $\begin{array}{r}12,300 \\
(4,400) \\
n=7\end{array}$ & $\begin{array}{r}14,300 \\
(3,600) \\
n=6\end{array}$ & $\begin{array}{r}15,400 \\
(4,700) \\
\mathrm{n}=7\end{array}$ & Markets \\
\hline Local companies' Tom Brown & & $\begin{array}{r}17,000 \\
(0) \\
\mathrm{n}=2\end{array}$ & & Supermarkets \\
\hline $\begin{array}{l}\text { Local companies' weanimix-type } \\
\text { products } * * *\end{array}$ & & $\begin{array}{r}23,900 \\
(7,700) \\
\mathrm{n}=10\end{array}$ & & Supermarkets \\
\hline Cerelac & & $\begin{array}{r}69,200 \\
(6,200) \\
\mathrm{n}=6 \\
\end{array}$ & & $\begin{array}{l}\text { Small shops } \\
\text { Supermarkets }\end{array}$ \\
\hline $\begin{array}{l}\text { Multinational companies' weaning } \\
\text { foods/infant formula (other than } \\
\text { Cerelac) }\end{array}$ & & $\begin{array}{r}147,200 \\
(34,600) \\
\mathrm{n}=7\end{array}$ & & Supermarkets \\
\hline
\end{tabular}

Note: numbers in parentheses are standard deviation; " $n$ " denotes the number of respondents for fermented maize dough and G/F vendors' Tom Brown and the number of the variety of products for the other categories.

* Low/High prices during the year are not prices observed during the fieldwork but prices reported by the vendors.

** Fermented maize dough can be used to prepare koko and banku. The difference in prices between fermented maize dough and the other products should be interpreted with caution. Fermented maize dough sold in the market is moist, while the other products are sold in a dried form. Therefore, the price per kg of dry-equivalent fermented maize dough would not be as low as presented in the table.

*** Includes products that were named Tom Brown but included ingredients other than maize and therefore seemed to be appropriate to be called weanimix. 


\section{Table 2: Characteristics of local food processing company respondents}

\begin{tabular}{|c|c|c|}
\hline & Characteristics & $\begin{array}{c}\text { processor } \\
(\mathrm{n}=10)\end{array}$ \\
\hline & Fewer than 5 & 3 \\
\hline Number of years the company & $5-10$ & 2 \\
\hline has been in business & $11-20$ & 4 \\
\hline & More than 20 & 1 \\
\hline & $1-5$ & 2 \\
\hline & $6-10$ & 4 \\
\hline (includino family members) & $11-15$ & 2 \\
\hline & More than 15 & 1 \\
\hline & Missing information & 1 \\
\hline & Less than 50 million & 6 \\
\hline Monthly revenue from all & 50-100 million & 1 \\
\hline products* $(\phi ;$ US $\$ 1 \approx \phi 9,200)$ & More than 100 million & 2 \\
\hline & Missing information & 1 \\
\hline & $1-5$ & 2 \\
\hline Number of products (including & $6-10$ & 2 \\
\hline weaning foods) & $11-15$ & 4 \\
\hline & More than 15 & 2 \\
\hline & Cowpeas (not soybeans) & $\overline{1}$ \\
\hline Weanimix-type product includes & Soybeans (not cowpeas)** & 7 \\
\hline as an ingredient: & Both cowpeas and soybeans & 1 \\
\hline & N.A.*** & 1 \\
\hline & Less than 2 & 2 \\
\hline Number of years the company is & & 4 \\
\hline producing weanimix-type & $6-10$ & 0 \\
\hline product & $10-15$ & 2 \\
\hline & Missing information \& N.A. & 2 \\
\hline & Less than $10 \%$ & 3 \\
\hline Share of weanimix-type product & $10-20 \%$ & 1 \\
\hline in the total revenue* & More than $20 \%$ & 2 \\
\hline & Missing information \& N.A. & 4 \\
\hline
\end{tabular}

* Revenue of the month for which the data were collected (mostly January or February 2007); approximate values were used for those respondents who reported, instead of the monthly revenue from all products, (1) the quantity and price of each product produced-the value of products was used as the approximate revenue, assuming that all the products were sold out in the month they were produced; and (2) the annual revenue in the past year-the figures were divided by 12 and used as approximate monthly revenue.

** Includes one respondent who was using soybeans at the time the interview was conducted, but reported also using cowpeas instead of soybeans depending on their availability.

*** This respondent did not produce weanimix-type product but produced Tom Brown and another weaning food containing soybeans. 
Table 3:Representative budgets to produce $1 \mathrm{~kg}$ of Tom Brown, cowpeaweanimix, and soybean-weanimix and estimated retail prices

\begin{tabular}{|c|c|c|c|c|}
\hline \multicolumn{2}{|c|}{ Retail price, retail margin, costs, return } & $\begin{array}{c}\mathrm{G} / \mathrm{F} \text { vendors } \\
(\phi)\end{array}$ & $\begin{array}{c}\text { Local } \\
\text { companies } \\
\text { LB } \\
(\varnothing)\end{array}$ & $\begin{array}{c}\text { Local } \\
\text { companies } \\
\text { HB } \\
(\varnothing)\end{array}$ \\
\hline \multirow{3}{*}{ Retail price } & TB & 14,300 & 18,300 & 17,500 \\
\hline & $c-W M$ & 15,400 & 19,800 & 18,900 \\
\hline & s-WM & 15,100 & 19,400 & 18,500 \\
\hline \multirow{3}{*}{ Retail margin $(29 \%)$} & TB & & 4,200 & 4,000 \\
\hline & $c-W M$ & & 4,500 & 4,300 \\
\hline & s-WM & & 4,400 & 4,200 \\
\hline \multirow{3}{*}{ Processor price } & TB & & 14,200 & 13,500 \\
\hline & $\mathrm{c}-\mathrm{WM}$ & & 15,300 & 14,600 \\
\hline & s-WM & & 15,000 & 14,300 \\
\hline \multirow{3}{*}{ Raw material } & TB & 3,900 & 3,900 & 3,800 \\
\hline & $c-W M$ & 5,000 & 5,000 & 4,900 \\
\hline & s-WM & 4,700 & 4,700 & 4,600 \\
\hline \multicolumn{2}{|l|}{ Wage } & 0 & 5,000 & 1,300 \\
\hline \multicolumn{2}{|l|}{ Equipment* } & 900 & 900 & 400 \\
\hline \multicolumn{2}{|l|}{ Electricity } & 0 & 300 & 100 \\
\hline \multicolumn{2}{|c|}{ Fuel (excl. fuel for vehicle) } & 400 & 800 & 500 \\
\hline \multicolumn{2}{|c|}{ Water } & 0 & 0 & 100 \\
\hline \multicolumn{2}{|c|}{ Rent } & 0 & 0 & 200 \\
\hline \multicolumn{2}{|c|}{ Transportation (incl. fuel for vehicle) } & 0 & 3,500 & 700 \\
\hline \multicolumn{2}{|c|}{ Printing \& Stationery } & 0 & 2,200 & 1,800 \\
\hline \multicolumn{2}{|c|}{ Telecommunication } & 0 & 500 & 200 \\
\hline \multicolumn{2}{|c|}{ Packaging material $* *$} & 0 & 400 & 700 \\
\hline \multicolumn{2}{|c|}{ Miscellaneous } & 0 & 400 & 600 \\
\hline \multirow{3}{*}{ Total cost } & TB & 5,200 & 18,100 & 10,500 \\
\hline & $c-W M$ & 6,300 & 19,200 & 11,600 \\
\hline & s-WM & 6,000 & 18,900 & 11,300 \\
\hline \multicolumn{2}{|l|}{ Return } & 9,100 & $-3,900$ & 3,000 \\
\hline
\end{tabular}

Note: LB: low-profit representative budget; HB: high-profit representative budget; TB: Tom Brown; cWM: cowpea-weanimix; s-WM; soybean-weanimix.

* Equipment cost for $\mathrm{G} / \mathrm{F}$ vendors is the cost of custom milling.

** The cost of packaging material was missing for both of the LB respondents. An assumed value of $\varnothing 400$ was derived using the data provided by other respondents. 


\section{Table 4:Estimated smallest and largest differences in retail prices of local companies' cowpea-weanimix and soybean-weanimix}

\begin{tabular}{|c|c|c|c|c|c|}
\hline \multirow{2}{*}{$\begin{array}{c}\text { Price- } \\
\text { competitiveness } \\
\text { of c-WM with } \\
\text { s-WM }\end{array}$} & \multirow{2}{*}{$\begin{array}{l}\text { Input- } \\
\text { output } \\
\text { ratio** }\end{array}$} & \multicolumn{2}{|c|}{$\begin{array}{l}\text { Price of raw materials } \\
(\notin / \mathrm{kg})^{* *}\end{array}$} & \multirow{2}{*}{$\begin{array}{l}\text { Retail } \\
\text { margin*** }\end{array}$} & \multirow{2}{*}{$\begin{array}{c}\text { Difference } \\
\text { in prices of } \\
\text { c-WM and } \\
\mathrm{s}-\mathrm{WM} \\
(\phi / \mathrm{kg}) \\
\end{array}$} \\
\hline & & Cowpeas & Soybeans & & \\
\hline Highest & 0.85 & 5,200 & 4,500 & 0.13 & 100 \\
\hline Current & 0.77 & 5,500 & 4,100 & 0.29 & 400 \\
\hline Lowest & 0.70 & 6,200 & 3,900 & 0.47 & 700 \\
\hline
\end{tabular}

Note: c-WM: cowpea-weanimix; s-WM; soybean-weanimix.

* The current value of 0.77 is the mean of the input-output ratios of the two representative budgets.

** These combinations assume that the price of cowpeas could become the highest when the price of soybeans is the lowest, and vice-versa.

*** The minimum value of 0.13 is the mean retail margin of small shop respondents (assuming that small shops do not collect the 15\% Value Added Tax/National Health Insurance Scheme); the maximum value of 0.47 is the mean retail margin of supermarket respondents (including the VAT/NHIS). 


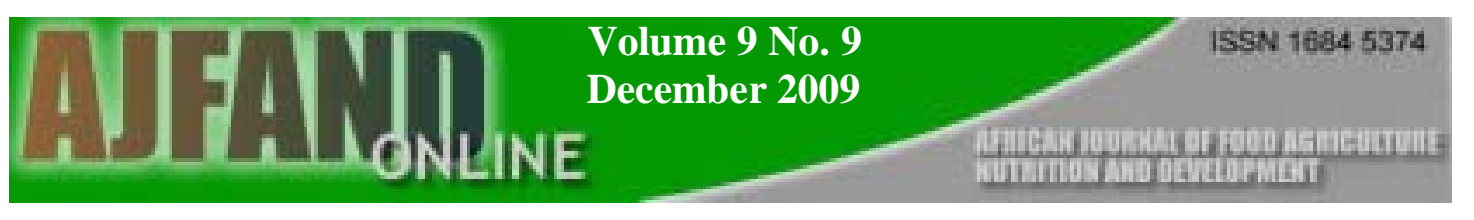

Table 5:Estimated smallest and largest differences in retail prices of local companies' cowpea-weanimix and Tom Brown

\begin{tabular}{|c|c|c|c|c|c|c|}
\hline \multirow{2}{*}{$\begin{array}{c}\text { Price- } \\
\text { competitiveness } \\
\text { of c-WM with } \\
\text { TB }\end{array}$} & \multirow{2}{*}{$\begin{array}{l}\text { Input- } \\
\text { output } \\
\text { ratio* }\end{array}$} & \multicolumn{3}{|c|}{ Price of raw materials $(\phi / \mathrm{kg})$} & \multirow{2}{*}{$\begin{array}{c}\text { Retail } \\
\text { margin** }\end{array}$} & \multirow{2}{*}{$\begin{array}{l}\text { Difference in } \\
\text { prices of c- } \\
\text { WM and TB } \\
(\varnothing / \mathrm{kg})\end{array}$} \\
\hline & & Maize & Cowpeas & Groundnuts & & \\
\hline Highest & 0.85 & 3,800 & 5,200 & 6,200 & 0.13 & 600 \\
\hline Current & 0.77 & 3,000 & 5,500 & 7,700 & 0.29 & $1,400-1,500$ \\
\hline Lowest & 0.70 & 2,500 & 6,200 & 8,500 & 0.47 & 2,400 \\
\hline
\end{tabular}

Note: TB: Tom Brown; c-WM: cowpea-weanimix.

* The current value of 0.77 is the mean of the input-output ratios of the two representative budgets.

** The minimum value of 0.13 is the mean retail margin of small shop respondents (assuming that small shops do not collect the 15\% Value Added Tax/National Health Insurance Scheme); the maximum value of 0.47 is the mean retail margin of supermarket respondents (including the VAT/NHIS). 


\section{Table 6:Estimated lowest and highest retail prices of local companies' cowpea- weanimix}

\begin{tabular}{|c|c|c|c|c|c|c|c|c|}
\hline \multirow{2}{*}{$\begin{array}{c}\text { Retail } \\
\text { price } \\
\text { estimate }\end{array}$} & \multirow{2}{*}{$\begin{array}{l}\text { Bud- } \\
\text { get }\end{array}$} & \multirow{2}{*}{$\begin{array}{l}\text { Input- } \\
\text { output } \\
\text { ratio }\end{array}$} & \multicolumn{3}{|c|}{ Price of raw materials $(\varnothing / \mathrm{kg})$} & \multirow{2}{*}{$\begin{array}{c}\text { Capacity } \\
\text { utilization }\end{array}$} & \multirow{2}{*}{$\begin{array}{l}\text { Retail } \\
\text { margin }\end{array}$} & \multirow{2}{*}{$\begin{array}{l}\text { Retail } \\
\text { price } \\
(\phi / \mathrm{kg})\end{array}$} \\
\hline & & & Maize & Cowpeas & $\begin{array}{l}\text { Ground- } \\
\text { nuts }\end{array}$ & & & \\
\hline \multirow{2}{*}{$\begin{array}{l}\text { Lowest } \\
\text { estimate }\end{array}$} & LB & \multirow{2}{*}{0.85} & \multirow{2}{*}{2,500} & \multirow{2}{*}{5,200} & \multirow{2}{*}{6,200} & \multirow{2}{*}{ Increased* } & \multirow{2}{*}{0.13} & 14,800 \\
\hline & HB & & & & & & & 12,200 \\
\hline \multirow{2}{*}{$\begin{array}{l}\text { Highest } \\
\text { estimate }\end{array}$} & LB & \multirow{2}{*}{0.70} & \multirow{2}{*}{3,800} & \multirow{2}{*}{6,200} & \multirow{2}{*}{8,500} & \multirow{2}{*}{ Current } & \multirow{2}{*}{0.47} & 24,900 \\
\hline & HB & & & & & & & 24,100 \\
\hline
\end{tabular}

Note: LB: low-profit representative budget; HB: high-profit representative budget.

* To conduct sensitivity analysis with regard to increase in capacity utilization, the following procedures were used: first, for each respondent, production quantity (in $\mathrm{kg}$ ) per worker per hour was calculated (not for weanimix-type product alone, but including all the products produced by the respondents); second, it was assumed that: (1) the respondent having the highest value of production quantity per worker per hour was operating at its full capacity; (2) the other respondents were operating under their capacity and could increase the volume of production until their production quantity per worker per hour would reach the value of the full capacity respondent, without requiring an increase in fixed costs; and (3) when the volume of production increased, there would be no change in average variable costs (i.e., assumption of constant returns to scale); and third, each respondent's budget was recalculated based on these assumptions and two representative budgets were reconstructed (with the same combinations of respondents that were selected to construct the original LB and HB). Furthermore, for the HB, it was assumed that they could cut their per-unit returns (i.e., processing margin) to one-half of the original value. Without this assumption, the estimated lowest retail price of cowpea-weanimix for the HB would be $\phi 13,900 / \mathrm{kg}$, instead of $\phi 12,200 / \mathrm{kg}$. This difference indicates that the level of processing margin greatly affects the retail price of weanimix. 


\section{REFERENCES}

1. Nti CA and WA Plahar Chemical and biological characteristics of West African weaning food supplemented with cowpea (Vigna unguiculata). Plant Foods Hum. Nutr. 1995; 48: 45-54.

2. Onofiok NO and DO Nnanyelugo Weaning foods in West Africa: Nutritional problems and possible solutions. Food and Nutrition Bulletin 19: 1. Tokyo. United Nations University Press, 1998.

3. Afoakwa EO, Sefa-Dedeh S and E Sakyi-Dawson Effects of cowpea fortification, dehydration method and storage time on some quality characteristics of maize-based traditional weaning foods. Afr. J. Food Agr. Nutr. Dev. 2004; 4: 1 .

4. Annan NT and WA Plahar Development and quality evaluation of a soyfortified Ghanaian weaning food. Food and Nutrition Bulletin 16: 3. Tokyo. United Nations University Press, 1995.

5. Bentley ME, Dickin KL, Mebrahtu S, Kayode B, Oni GA, Verzosa CC, Brown KH and JR Idowu Development of nutritionally adequate and culturally appropriate weaning food in Kwara state, Nigeria: An interdisciplinary approach. Soc. Sci. Med. 1991; 33, 10: 1103-1111.

6. Egounlety M, Aworh OC, Akingbala JO, Houben JH and MC Nago Nutritional and sensory evaluation of tempe-fortified maize-based weaning foods. Int. J. Food Sci. Nutr. 2002; 53: 15-27.

7. El-Habashy M, Phillips RD, Eitenmiller RR, Mostafa MM, Rahma E and A El-Bedaiwy Computer optimization of weaning food formulas. J. Food Quality 1995; 18: 295-312.

8. El-Habashy M, Phillips RD, Eitenmiller RR, Mostafa MM, Rahma E and A El-Bedaiwy Protein quality assessment of computer optimized weaning formulas J. Food Quality 1997; 20: 267-277.

9. Lartey A, Manu A, Brown KH, Peerson JM and KG Dewey A randomized, community-based trial of the effects of improved, centrally processed complementary foods on growth and micronutrient status of Ghanaian infants from 6 to 12 mo of age. Am. J. Clin. Nutr. 1999; 70: 391-404.

10. Mensa-Wilmot Y, Phillips RD, Lee J and RR Eitenmiller Formulation and evaluation of cereal/legume-based weaning food supplements. Plant Foods Hum. Nutr. 2003; 58: 1-14. 
11. Plahar WA, Onuma Okezie B and CK Gyato Development of a high protein weaning food by extrusion cooking using peanuts, maize and soybeans. Plant Foods Hum. Nutr. 2003; 58: 1-12.

12. Colecraft EK, Marquis GS, Bartolucci AA, Pulley LV, Owusu WB and HM Maetz A longitudinal assessment of the diet and growth of malnourished children participating in nutrition rehabilitation centres in Accra, Ghana. Public Health Nutr. 2003; 7, 4: 487-494.

13. Davis DW, Oelke EA, Oplinger ES, Doll JD, Hanson CV and DH Putnam Cowpea. In University of Wisconsin-Extension, Cooperative Extension. Alternative field crops manual. 1992. Retrieved August 2, 2006, from http://corn.agronomy.wisc.edu/AlternativeCrops/Cowpea.htm.

14. Dovlo FE, Williams CE and L Zoaka Cowpeas: Home preparation and use in West Africa. Ottawa. International Development Center, 1976.

15. Langyintuo AS, Lowenberg-DeBoer J, Faye M, Lambert D, Ibro G, Moussa B, Kergna A, Kushwaha S, Musa S and G Ntoukam Cowpea supply and demand in West and Central Africa. Field Crop. Res. 2003; 82: 215-231.

16. Mensa-Wilmot Y, Phillips RD and JL Hargrove Protein quality evaluation of cowpea-based extrusion cooked cereal/legume weaning mixtures. Nutr. Res. 2001; 21: 849-857.

17. Mensa-Wilmot Y, Phillips RD and S Sefa-Dedeh Acceptability of extrusion cooked cereal/legume weaning food supplements to Ghanaian mothers. Int. J. Food Sci. Nutr. 2001; 52: 83-90.

18. Leung WW Food composition table for use in Africa. Bethesda, Maryland. US Department of Health, Education, and Welfare; Rome. Food and Agriculture Organization of the United Nations, 1968.

19. B/C CRSP. Bean/Cowpea Collaborative Research Support Program. Regional project research and training workplans (October 1, 2006 to September 30, 2007). Technical Committee Meeting, Memphis, Tennessee, May 10-12, 2006.

20. Lambot $\mathbf{C}$ Industrial potential of cowpea. In CA Fatokun, SA Tarawali, BB Singh, PM Kormawa and M Tamò (Eds). Challenges and opportunities for enhancing sustainable cowpea production (pp. 367-375). Proceedings of the World Cowpea Conference III held at the International Institute of Tropical Agriculture (IITA), Ibadan, Nigeria, 4-8 September 2000. IITA, Ibadan, Nigeria, 2002.

21. Casley DJ and DA Lury Data collection in developing countries. 2nd ed. New York. Clarendon Press, 1987. 
22. Harsh SB, Connor LJ and GD Schwab Managing the farm business. Englewood Cliffs, NJ. Prentice-Hall, 1981.

23. Nagai T Competitiveness of cowpea-based processed products: A case study in Ghana. M.S. thesis, Michigan State University, 2008.

24. Plahar WA, Nti CA and NT Annan Effect of soy-fortification method on the fermentation characteristics and nutritional quality of fermented maize meal. Plant Foods Hum. Nutr. 1997; 51: 365-380.

25. Sefa-Dedeh $\mathbf{S}$ Final report for USAID associate cooperative agreement No. 641A-00-03-0003. Ghana Private-Public Partnership Food Industry Development Program, 2005. 